\title{
The Effect of Peat Soil on Room Temperature in Type-36 Housing in Palangkaraya
}

\author{
David Ricardo \\ Faculty of Engineering \\ Universitas Atma Jaya Yogyakarta \\ Indonesia
}

\author{
A Djoko Istiadji \\ Faculty of Engineering \\ Universitas Atma Jaya Yogyakarta \\ Indonesia \\ istiadji.dj@gmail.com
}

\author{
Prasasto Satwiko \\ Faculty of Engineering \\ Universitas Atma Jaya Yogyakarta \\ Indonesia \\ prasasto.satwiko@uajy.ac.id
}

\author{
Nimas Sekarlangit \\ Faculty of Engineering \\ Universitas Atma Jaya Yogyakarta \\ Indonesia \\ nimas.sekarlangit@uajy.ac.id
}

\begin{abstract}
Settlement and housing development is the main activity in arranging the spatial layout of Palangkaraya, focusing mainly on the small-type house like type-36. Most of the type-36 housings planned by the developer are on peatland. Indonesia's Public Housing Minister states that the type-36 house is appropriate for the minimum health standard. The construction system used in type-36 housing in Palangkaraya is reinforced concrete frame construction, light concrete brick wall, ceramic floor, light steel roof (roof cover made of multiroof material), and rubble stone or chicken claw foundation, and located on peatland. The authors checked the peatland using an infrared camera (FLIR i5) as the instrument. The result showed that the most significant room heat gain came from conducted peat soil (heat transfer) toward the foundation and then followed with the building's floor and wall. Such the process is called thermal bridges. From the thermal bridges process, the authors tried to solve the problem by developing thermal barriers to overcome the heat entering the type-36 house. This research used an experimental and simulation method using CFD-CADalyzer software.
\end{abstract}

Data included peat temperature affecting the building temperature collected using an IR FLIR i5 camera and an infrared thermometer. Soil temperature, air humidity, and wind speed data were taken from Palangkaraya's BMKG (Meteorology, Climatology, and Geophysics Agency). The research result was a foundation design that reduced heat gain (thermal barriers) due to the thermal bridges process. It added thermal insulation made of mineral wool and polyurethane to the existing foundation. These materials are integrating the rubble stone foundation by adding heat-insulating (mineral wool and polyurethane) materials only. The materials lowered the room temperature from $47.4^{\circ} \mathrm{C}$ and $45.8^{\circ} \mathrm{C}$ to $340 \mathrm{C}-33 \circ \mathrm{C}$. The not recommended alternative is to use sole (chicken claw) foundation structure on which the air cavity was developing. It makes the room temperature hotter, due to air expansion process occurring because of heat transfer on floor and wall materials without using heat insulation.

Keywords: peat temperature, heat transfer, thermal bridges, thermal barriers

\section{INTRODUCTION}

Settlement and housing development is the main activity in arranging the spatial layout of Palangkaraya. The development strategy was directed to the development to follow the existing housing and the land appropriate to the activity development. The housing offered by the developer consists of many types: from small to large ones. Small-type house such as type-36 is the one preferred widely by Palangkaraya people.

Moreover, the government, through the State Minister for Public Housing, is developing an inexpensive type-36 house program (with its area of 36 square meters). Indonesia's Public Housing Minister states that the type-36 house is appropriate for the minimum health standard (Figure 1). The construction system used in type-36 housing in Palangkaraya is reinforced concrete frame construction, light concrete brick wall, ceramic floor, light steel roof (roof cover made of multi roof material), and rubble stone or chicken claw foundation, and located on peatland.

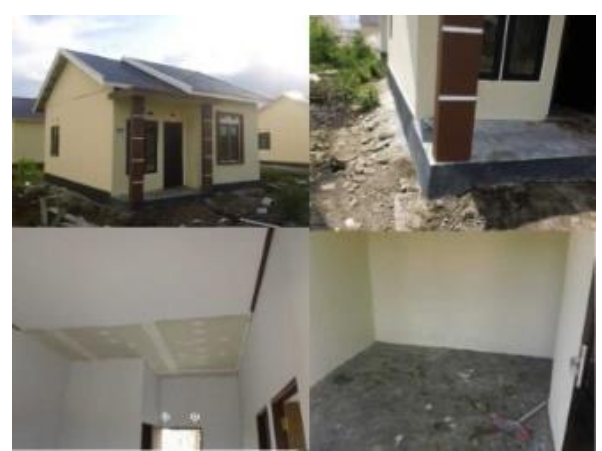

Fig. 1. An example of a type-36 house in Kecipir Street, Palangkaraya. Source: author, 2016

The early stage of research was to observe Borneo Housing, Palangkaraya using a Flir i5 camera, and temperature analysis are conducting using the Flir Tools program. The research was leading to find out the size of heat gain coming from peat soil. Soil surface temperature captured by the infrared camera was $47.4^{\circ} \mathrm{C}$ and $45.8^{\circ} \mathrm{C}$ at two different times. The author used a $30^{\circ} \mathrm{C}-51^{\circ} \mathrm{C}$ scale as the margin of soil temperature occurring in the field (Figure 2). 


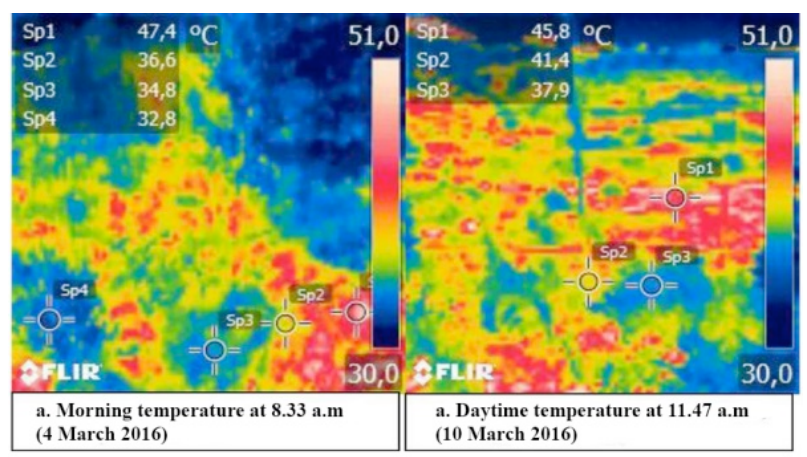

Fig. 2. IR Flir i5 camera was imaging on the peat soil surface at the research location.

Source: author, 2016

TABLE I. INFORMATION ABOUT PALANGKARAYA

\begin{tabular}{|l|l|}
\hline $\begin{array}{l}\text { Palangkaraya (Capital of } \\
\text { Central Borneo Province) }\end{array}$ & \multicolumn{1}{|c|}{ Information } \\
\hline Coordinate & $\begin{array}{l}113^{\circ} 30^{\prime} 114^{\circ} 07^{\prime} \text { East Longitude } \\
1^{\circ} 35^{\prime}--2^{\circ} 24^{\prime} \text { South Latitude }\end{array}$ \\
\hline Air Temperature & $23^{\circ} \mathrm{C}--34^{\circ} \mathrm{C}$ \\
\hline Highest humidity & $86^{\circ}--87 \%$ (March-May) \\
\hline Lowest humidity & $83^{\circ}--80 \%$ (August-October) \\
\hline Highest wind speed & $1.81-1.83 \mathrm{~m} / \mathrm{s}$ (August and October) \\
\hline Lowest wind speed & $1.17-1.00 \mathrm{~m} / \mathrm{s}$ (May and June) \\
\hline
\end{tabular}

The next stage was to measure the temperature of building as the effect of high soil surface temperature. The most significant (dominant) heat flow departs from the warm foundation and then comes from the roof to the upper wall. It clearly from color temperature indicators that top wall temperature (color and temperature margin were setting between $25^{\circ} \mathrm{C}$ and $69^{\circ} \mathrm{C}$ ) is higher than that in the lower wall $(46.5 \mathrm{oC})$. In the thermal bridges event, the largest (dominant) heat yielded was the heat flowing through the foundation toward the wall through the conduction process coming from peat soil heat (Figure 3).

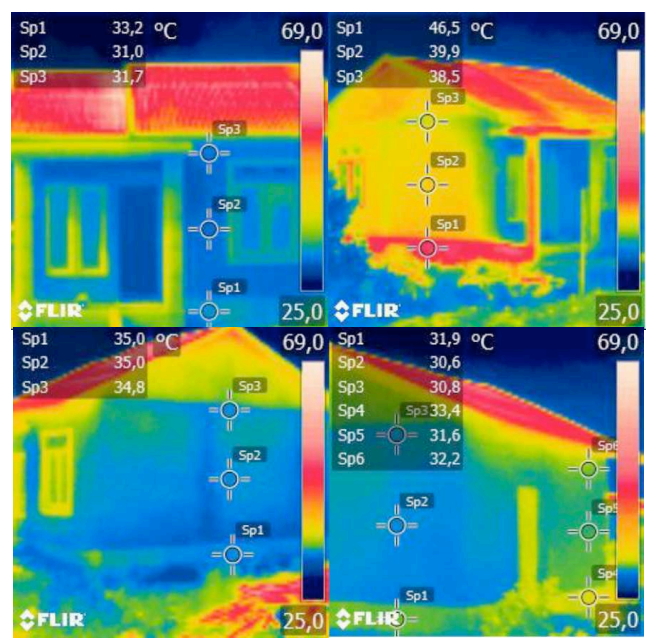

Fig. 3. Flir i5 camera was imaging on the building. Source: author: 2016
Considering the heat entry phenomenon (thermal bridges), the authors attempted to deal with the heat by preventing the heat from entering into the building or called thermal barriers. Thereby, it was expected to minimize the room heat gain. This study was to find out the path of heat entry (thermal bridges) occurring, thereby obtaining a method to limit the heat entering (thermal

\section{METHOD}

The method employed field thermal measurement and heat flow computer simulation using CFD CADAlyzer software for sample type-36 housing. The thermal measurement of the building was doing to obtain thermal bridges. A new model of the foundation was simulating to obtain an excellent thermal barrier system by adding insulating material and changing the structural system.

Data included peat temperature affecting the building temperature collected using an IR FLIR i5 camera and an infrared thermometer. The data of soil temperature, air humidity, and wind speed is taking from Palangkaraya's BMKG (Meteorology, Climatology, and Geophysics Agency). Measurement was conducted during bright cloudy weather so that the temperature was relatively stable. The data is taking in the morning, afternoon, evening, and night at clear weather. The research took place in Kecipir Street, Palangkaraya, exactly in type-36 Borneo Sejahtera Housing.

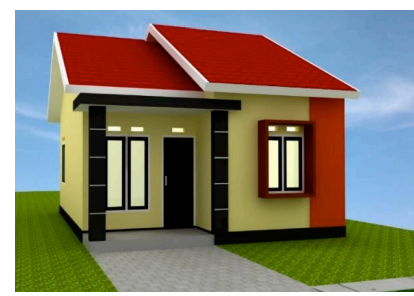

Fig. 4. Type-36 Housing Modeling in Palangkaraya City Source: Author, 2016

\section{THEORY}

Centre Borneo's forest area has varying types of peat (Figure 5). Peat soil temperature measured is the one on opened land (Table II). The peat soil temperature has no significant difference between years and between areas.

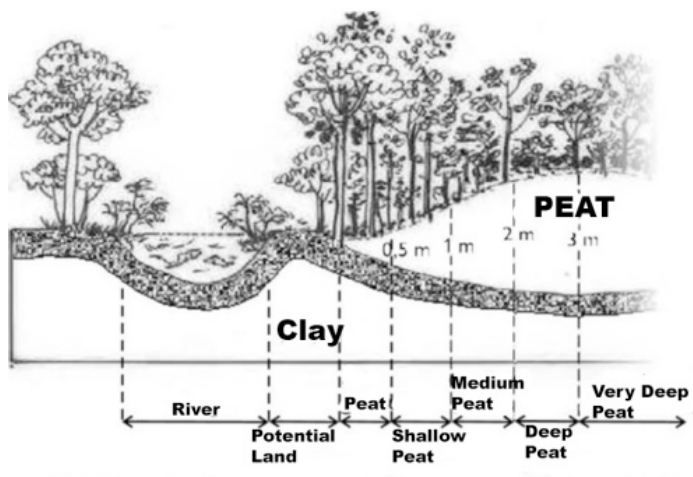

Fig. 5. The condition of peat soil in Central Kalimantan's forest area. Source: Weatland International Indonesian Programme, 2003 
TABLE II. PEAT SOIL TEMPERATURE ON JULY 23, 2014

\begin{tabular}{|c|c|c|}
\hline $\begin{array}{c}\text { Time (Hour) } \\
\text { Temperature with }\end{array}$ & 2 cm depth & $\begin{array}{c}\text { The temperature at 5 } \\
\text { cm depth }\end{array}$ \\
\hline 10.00 Local Time & $30.9^{\circ} \mathrm{C}$ & $27.4^{\circ} \mathrm{C}$ \\
\hline 11.30 Local Time & $35.1^{\circ} \mathrm{C}$ & $31.3^{\circ} \mathrm{C}$ \\
\hline 14.00 Local Time & $31.6^{\circ} \mathrm{C}$ & $31.1^{\circ} \mathrm{C}$ \\
\hline
\end{tabular}

\section{A. Heat transfer system from foundation}

The heat transfer system in the foundation occurs with the conduction process. In this research, the thermal conductivity is calculating from the slope obtained by linear regression of the natural logarithm of the temperature versus time. The initial freezing temperature and ice fraction were determined at every temperature of analysis for further use in the models, thereby finding out the temperature yielded in the building [1]. It was illustrating in figure 6.

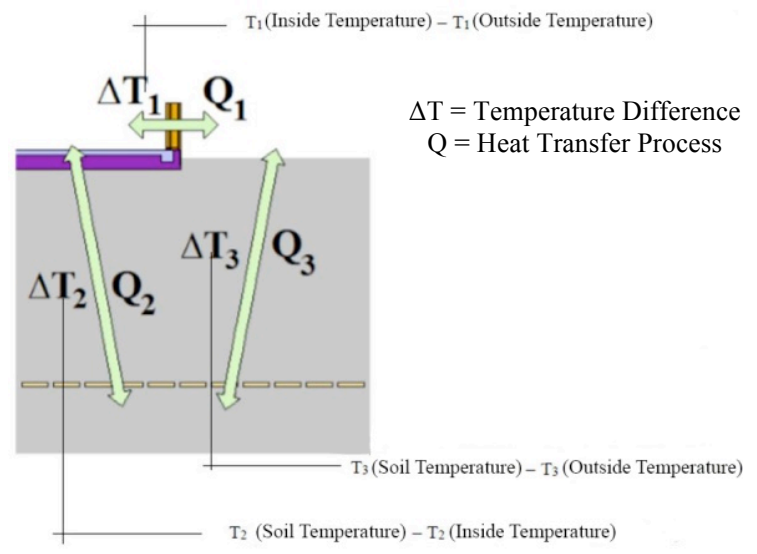

Fig. 6. Illustration of temperature and heat flows difference between indoor, outdoor, and soil.

Source: Nyberg, 2011

\section{B. Heat transfer system in material}

The thermal behavior of construction material is dependent on the thermal conductivity of soil particles, micro-pore structure, and its composing liquid (air and or humidity). The thermal response of the building envelope is determining by the thermal characteristics of individual construction materials and its configuration. The factors that affect the thermal properties of a material, especially thermal conductivity, must be considered to correctly determine the energy performance of the materials by its composing material's configuration, namely individual microstructure of its composing material[2]. The heat transfer flow process in the material can see in Figure 7.

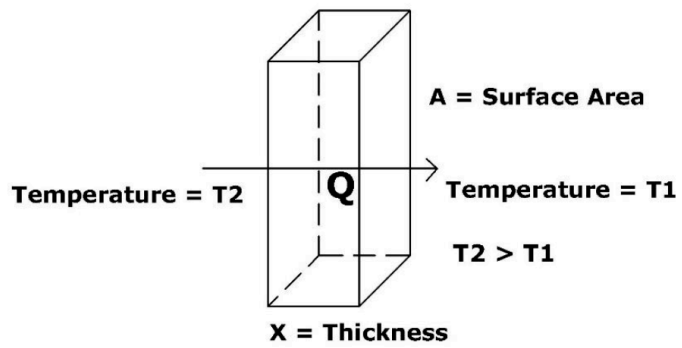

Fig. 7. Heat Transfer Flow process in material Source: http://energy-models.com, retrieved on December 20, 2016
Formula of Heat Transfer Flow in material:

$$
\mathbf{Q}=\mathbf{A} \frac{\mathbf{k}}{\mathbf{X}}\left(\mathbf{T}_{2}-\mathbf{T}_{1}\right)
$$

Where:

$$
\begin{array}{ll}
\mathrm{Q} & =\text { Heat transfer flow rate }[\mathrm{W}], \\
\mathrm{A} & =\text { Surface area }[\mathrm{m} 2], \\
\mathrm{K} & =\text { Conductivity of building envelope }[\mathrm{W} / \mathrm{m} . \mathrm{K}], \\
\mathrm{X} & =\text { Homogeneous material thickness }[\mathrm{m}], \\
\mathrm{T} 2-\mathrm{T} 1 & =\text { Temperature different }[\mathrm{K}]
\end{array}
$$

\section{Heat transfer system on soil}

The soil heat conduction is related to the form and distribution of water in the soil [3] (Figure 8). Nevertheless, thermal conductivity in frozen soils is mainly controlling by air content and positively correlated with sub-zero temperatures $\left(-5\right.$ to $\left.-20^{\circ} \mathrm{C}\right)$. It slightly increases with increasing temperature $\left(5\right.$ to $\left.20^{\circ} \mathrm{C}\right)$ in thawed soil, and clear layers exist. The effect of temperature can decline for dry soil. The thermal conductivity of thawed soil is positively correlated with moisture content and shows nonlinear variation. The rate of increase is rapid during the early stages of thawing and then slows down. Saturated hydraulic conductivity decreases with depth. Potential soil matrices show large and spatially heterogeneous fluctuations due to feedback on soil moisture [4].

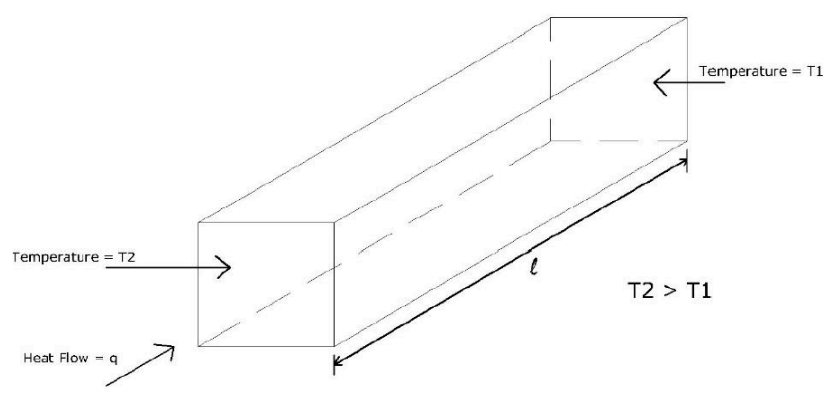

Fig. 8. The heat transfer system of the soil. Source: Farouki, 1981

Formula of Soil's Thermal Conductivity:

$$
\mathrm{k}=\frac{q}{\mathrm{~A}\left(\mathbf{T}_{2}-\mathbf{T}_{1}\right) / \mathrm{l}}
$$

Where:

$\mathrm{T} 2-\mathrm{T}=$ Temperature different $[\mathrm{K}]$,

$\mathrm{q}=$ Heat flows [W],

A $=$ Area $[\mathrm{m} 2]$,

$1=$ Length $/$ wide $[\mathrm{m}]$,

$\mathrm{k}=$ Conductivity $[\mathrm{W} / \mathrm{m} . \mathrm{K}]$

The temperature distribution inside the soil showed that the steady-state conditions were established faster in unsaturated experiments than the fully saturated case due to the lower thermal diffusivity of saturated soil [5]. Heat flow occurring on the soil always goes the surface upward with different fluid and solid positions (Figure 9) 


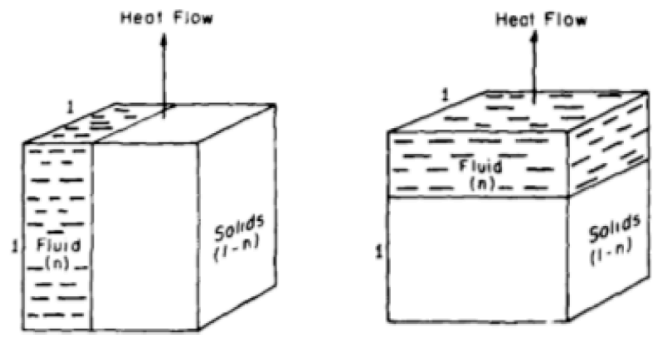

Fig. 9. Heat flow occurring on the soil. Source: Farouki, 1981

\section{Thermal bridges}

Thermal bridges zone can be found widely in the concrete columns, corners, window openings, and other parts (see Figures 10 and 11). Concrete part such as the integration of wall block, window, and door, as thermal bridges, has a low thermal insulating property. Condensation can occur and results in high humidity levels. The impact of the external wall on overheating could be defined in two ways. 1. the structure, through which the heat is transferring from the exterior. 2. it warms the interior or (less usual) as the structure, which contributes to the thermal stability of the interior by its accumulative ability [6]. The low temperature of the wall internal surface results in large condensation formation.
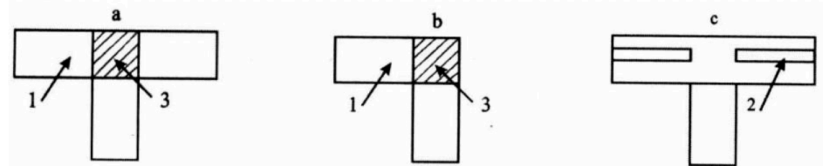

Fig. 10. Sketch of thermal bridges in transversal and longitudinal wall intersections.

Source: Savov, 2002

Notes:

$\mathrm{a}, \mathrm{c}-$ located on transversal wall intersection and $\mathrm{b}$ - located on the corner

1. Concrete rick or brick material

2. Fabricated concrete

3. Concrete material-coated steel
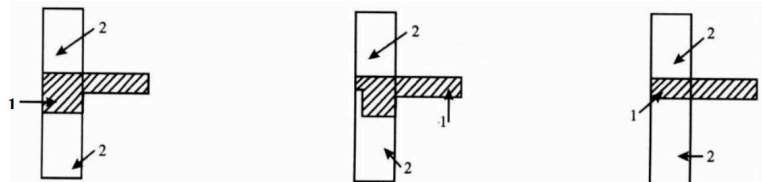

Fig. 11. Detail of thermal bridges section in external wall intersection and floor

Source: Savov, 2002

Note:

1. Floor block

2. Concrete brick or brick wall material

\section{E. Thermal barrier}

The thermal barrier has two methods: using an insulating technique and changing the building structure system. Thermal barrier coatings (TBCs) are protective coatings applied to the surface of hot metallic sections. TBCs are complex systems bringing the metallic and ceramic materials together, to function under highly demanding thermal cycling conditions. To that end, ceramic materials are further enhanced in terms of both thermal insulation efficiency and thermal expansion compliance in different ways and extend by different processing routes. Excellent thermal stability, a low thermal conductivity, a high coefficient of thermal expansion (CTE) in combination with a high fracture toughness are the main required properties for the ceramic topcoat on top of metallic components [7].

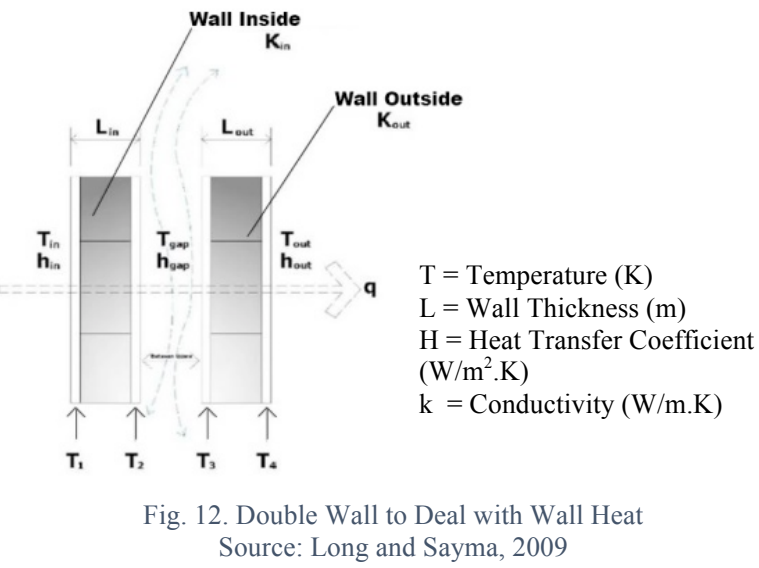

\section{RESUltS AND DisCUSSION}

\section{A. Result of thermal bridges simulation}

Considering the simulation conducted, the author found several results to develop thermal barriers (Table III).

TABLE III. SIMULATION VALUE IN THE EXISTING CONDITION OF THE BUILDING.

\begin{tabular}{ll}
\hline Material & Temperature \\
\hline Ceiling & $308 \mathrm{~K}-312 \mathrm{~K}$ \\
\hline Wall & $306 \mathrm{~K}-309 \mathrm{~K}$ \\
\hline Floor & $306 \mathrm{~K}-309 \mathrm{~K}$ \\
\hline Foundation & $309 \mathrm{~K}-314 \mathrm{~K}$ \\
\hline Ordinary Soil & $309 \mathrm{~K}-314 \mathrm{~K}$ \\
\hline Peat soil & $316 \mathrm{~K}-322.2 \mathrm{~K}$ \\
\hline
\end{tabular}

Source: Author's analysis, 2017

The highest temperature lies in peak soil surface area resulting from isothermal and heat-flux occurring between $316 \mathrm{~K}$ and $322 \mathrm{~K}(42.85-48.85 \mathrm{oC})$ on peat soil (Table 3$)$. Foundation, ordinary soil, floor, and wall parts are the ones with high temperature (Table III). Considering the result of simulation on thermal bridges, the main entrance of heat came from ordinary soil and conducted a foundation made of peat soil. Similarly, the wall part is affected by the foundation conducted by peat soil that has been treating with isothermal and heat flux.

\section{B. Construction modeling with heat insulation addition (simulations 1 and 2)}

The use of insulation is the most widely used method to deal with excessive room heat due to external factors such as solar radiation. In heat insulation simulation (simulation 1), 


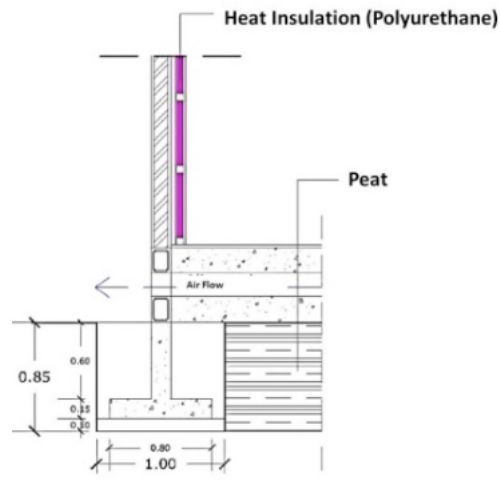

insulation is installing on floor and foundation areas constituting the areas encountering much heat coming from peat soil (Figure 13). In heat insulation simulation (simulation 2), to deal with solar radiation, insulation is added to the wall as well (Figure 14).

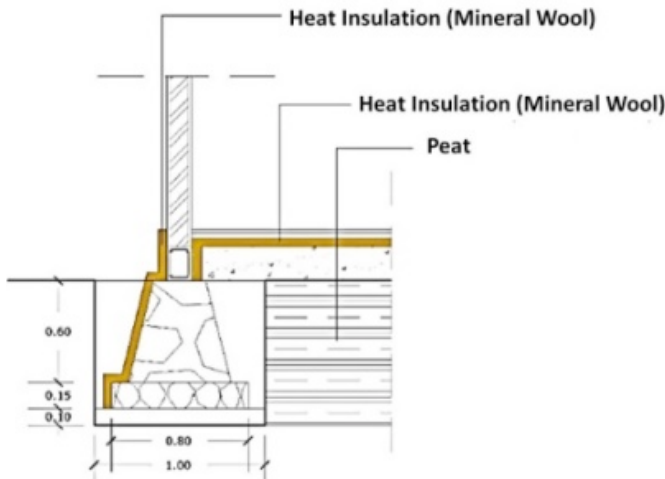

Fig. 13. Heat insulation on foundation and floor (alternative 1) Source: Author's analysis, 2016

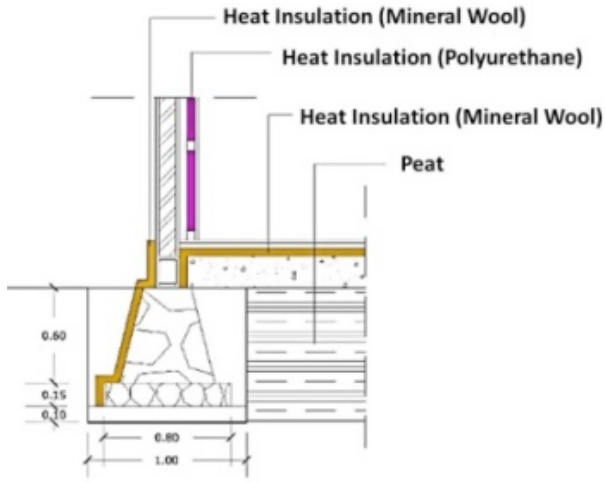

Fig. 14. Heat Insulation On Foundation, Floor, And Wall (Alternative 2) Source: Author's analysis, 2016

C. Construction modeling with heat insulation and construction structure change as a thermal barrier (simulations 3 and 4)

The change of structure made to deal with the heat concentrated on the area beneath the floor, common soil area. Simulation 3 was to develop air passage under the floor to forward the air in the foundation area to the side. It was then to develop heat insulation on the wall to prevent solar radiation on the wall (Figure 15). Simulation 4 is conducting by channeling the air either from below the floor or wall. The part is warm air ventilation that will flow continuously so that warm air will be changed continuously with the cooler one (Figure 16).

\section{TABLE IV. RESULT OF CFD SIMULATION}

\begin{tabular}{|l|l|}
\hline \multicolumn{1}{|c|}{ Activities } & \multicolumn{1}{c|}{ Result of Simulation } \\
\hline $\begin{array}{c}\text { Prior } \\
\text { Conding) }\end{array}$ & $\begin{array}{l}\text { The highest temperature lies on peat soil. It starts to } \\
\text { decrease on ordinary soil but increases again on the } \\
\text { floor (concrete material) part due to heat conduction } \\
\text { from foundation and concrete wall }\end{array}$ \\
\hline Simulation 1 & $\begin{array}{l}\text { Temperature tends to decrease to 1.5 m height } \\
\text { (ordinary soil area), but it increases again in the } \\
\text { room of building insignificantly, 316K - 322.2K } \\
\text { (peat soil and foundation parts) }\end{array}$ \\
\hline Simulation 2 & $\begin{array}{l}\text { Temperature decreases dramatically (graphic } \\
\text { decreases), and the insulating material used seems to } \\
\text { function well. Mainly, it was due to the addition of } \\
\text { wall insulating (polyurethane) material to muffle } \\
\text { conduction coming from foundation and floor, and } \\
\text { even room temperature is about 307 Kelvin (34oC). }\end{array}$ \\
\hline Simulation 3 & $\begin{array}{l}\text { Graphic decreases, but it seems to be flat on the } \\
\text { concrete floor area, and then temperature decreases } \\
\text { again, particularly in the interior. The decrease is } \\
\text { due to the addition of wall insulating (polyurethane) } \\
\text { material that can muffle heat conduction from the } \\
\text { foundation or floor. Peat soil has a high temperature }\end{array}$ \\
\hline
\end{tabular}


making the room temperature hotter, due to air expansion process occurring because of heat transfer on floor and wall materials without using heat insulation.

\section{REFERENCES}

[1] T. M. O. Giarola, C. G. Pereira, and J. V. Resende, "Thermal Conductivity of Mango Pulp (Mangifera indica L.) Cultivar 'ubari' in Freezing Temperatures," Int. J. Food Prop., vol. 19, no. 2, pp. 385-394, 2016.

Thermal barriers by priority order are simulation 2 (two), simulation 3 (three), simulation 1 (one), and simulation 4 (four). Out of all tests conducted, the main recommendation is giving by using a prior foundation (simulation 2) by adding heat insulation such as mineral wool and polyurethane only.

\section{CONCLUSION}

The most important thermal bridges process occurs due to the conduction process from peat soil at temperature $320 \mathrm{~K}$ $(47 \mathrm{oC})$ to ordinary soil, foundation, and floor. Conduction process departs from the presence of heat flux $(5.5 \mathrm{~W} / \mathrm{m} 2)$ on peat soil flowed toward the construction. All conduction processes have not included yet solar radiation that likely will make the room temperature higher.

The most effective thermal barriers were obtaining from insulating the heat from peat soil by mineral wool and polyurethane materials. These materials were integrated using the rubble stone foundation by adding heat-insulating (mineral wool and polyurethane) materials only. These materials can lower room temperature from $47^{\circ} \mathrm{C}$ (prior temperature) to $34 \mathrm{oC}-33 \mathrm{oC}$. The alternative not recommended is to use sole (chicken claw) foundation structure on which the air cavity was developed. It was
[2] Z. Pezeshki, A. Soleimani, A. Darabi, and S. M. Mazinani, "Thermal transport in Building materials," Constr. Build. Mater., vol. 181, pp. 238-252, 2018.

[3] Y. Xu, D. Sun, Z. Zeng, and H. Lv, "Effect of temperature on thermal conductivity of lateritic clays over a wide temperature range," Int. J. Heat Mass Transf., vol. 138, pp. 562-570, 2019.

[4] J. Chen et al., "A Study of Soil Thermal and Hydraulic Properties and Parameterizations for CLM in the SRYR," J. Geophys. Res. Atmos., vol. 123, no. 16, pp. 8487-8499, 2018.

[5] A. Moradi, K. M. Smits, N. Lu, and J. S. McCartney, "Heat transfer in unsaturated soil with application to borehole thermal energy storage," Vadose Zo. J. vol. 15, no. 10, 2016.

[6] R. Ponechal and D. Staffenova, "Impact of external wall insulation thickness on internal surface temperature behavior," MATEC Web Conf., vol. 117, 2017.

[7] E. Bakan and R. Vaßen, "Ceramic Top Coats of PlasmaSprayed Thermal Barrier Coatings: Materials, Processes, and Properties," J. Therm. Spray Technol., vol. 26, no. 6, pp. 992-1010, 2017. 